\title{
Surfaces with high precision of roughness after grinding
}

Eng. MSc. Martin Novak, Ph.D.

Faculty of Production Technology and Management, J. E. Purkyne University in Usti nad Labem. Czech Republic. Europe.E-mail: novak@fvtm.ujep.cz.

The traditional approach to grinding is to operate within the limits of surface quality. The requirements for surface quality in grinding are higher than those in other common machining operations such as turning and milling. The surface quality of machined parts is very important for precise production and assembly. When we focus on roughness parameters after grinding, we can establish the limits of these parameters for typical grain materials: $\mathrm{Al}_{2} \mathrm{O}_{3}, \mathrm{SiC}, \mathrm{CBN}, \mathrm{SG}$ and others. Increasing demands on accuracy and quality of production leads to research concerned with the properties of these materials and the surface quality after grinding. This paper shows new possibilities for the ground surface with focus on surface roughness obtained under varying combinations of cutting conditions. The influence of the grinding wheel, cutting parameters and coolant on higher surface quality is assessed by roughness parameters $\mathrm{Ra}, \mathrm{Rz}, \mathrm{Rt}$ and the Material portion of a surface profile. These highprecision ground surfaces are shown to have a Nanometres $\left(1^{-9}\right)$ unit topography demonstrating that the process is able to replace other finishing technologies such as superfinishing or honing.

Keywords: Grinding, High precision, Roughness, Surface

Acknowledgement

Above mentioned results were created by means of national project GA CR No. 101/09/0504.

\section{References}

[1] BASSOLI, E. etc., (2011), Grinding Micromechanisms of a Sintered Friction Material, in: Journal of Manufacturing Science and Engineering, ASME, Feb 2011, vol. 133., 6 pp.

[2] HOLESOVSKY, F., NOVAK, M. (2010). Influence of grinding on machine parts with desing notches, in: Manufacturing Technology IX, UJEP, Usti n. Labem, 40-46 pp.

[3] KOCMAN, K. (2010). Analyza vyvojovych brousicich kotoucu na bazi mikrokrystalickeho korundu, in: Strojirenska technologie, vol. XV., no. 3., UJEP, Usti nad Labem, 40-47 pp.

[4] LUKOVICS, I., BILEK, O., HOLEMY, S. (2010). Development of Grinding Wheels for Tools Manufacturing, in: Manufacturing Technology, vol. X., no. 10., UJEP, Usti nad Labem, 10-16 pp.

[5] MARINESCU, I., D., et all. (2007). Handbook of Machining with Grinding wheels. Boca Raton: CRC Press. $592 \mathrm{pp}$.

[6] NOVAK, M. (2011). Surface quality of hardened steels after grinding. in: Manufacturing Technology, vol. XI., no. 11., UJEP, Usti nad Labem, 55-59 pp.

[7] MALKIN, S. (1989). Grinding Technology: Theory and applications of machining with abrasives. SME. 275pp.

[8] KUNDRAK, J. (2011). Alternative machining procedures of hardened steels, in Manufacturing Technology, vol. XI., no. 11., UJEP, Usti nad Labem, 32-39 pp.

[9] NOVAK M., LATTNER M., RUZICKA L., HOLESOVSKY F., (2010). Grinding and surface quality parameters at automotive parts machining, in Manufacturing Technology, vol. X., no. 10., UJEP, Usti nad Labem, 36$38 \mathrm{pp}$.

[10] HOLESOVSKY, F., NOVAK, M. (2010). Grinding and its influence to ground surface durability. Proceedings of International Conference on Advances in Materials and Processing Technologies. Paris. Publisher: Amer INST Physics, Melville, NY, USA. ISBN 978-0-7354-0871-5. WOS: 000287169300158.

[11] NOVAK, M. (2012). Influence of the Corrosion Surrounding on Surface Quality of Ground Hardened Steels In Key Engineerings Materials, vol. 496: Precision Machining IV. TTP. Zurich. $25-30$ pp. WOS:000302674400005

[12] NOVAK, M., NAPRSTKOVA, N., RUZICKA. L. (2012). New ways in aluminium alloys grinding. In Key Engineerings Materials, vol. 496: Precision Machining IV. TTP. Zurich. 132 - 137 pp. WOS:000302674400023

Paper number: M201215

Manuscript of the paper recieved in 2011-12-28. The reviewers of this paper: Prof. Dr. h. c. Ioan D. Marinescu, MSc., Ph.D. and Dr. Michael N. Morgan, MSc. 